\title{
A Novel Loop Heat Pipe Based Cooling System for Battery Packs in Electric Vehicles
}

\author{
Marco Bernagozzi $^{\mathrm{a},{ }^{*}}$, Anastasios Georgoulas ${ }^{\mathrm{a}}$, Nicolas Michéa ${ }^{\mathrm{a}}$ Cedric Rouaud ${ }^{\mathrm{b}}$, Marco Marengo $^{\mathrm{a}}$ \\ ${ }^{a}$ Advanced Engineering Centre, University of Brighton, Brighton, UK \\ ${ }^{\mathrm{b}}$ Ricardo plc, Shoreham-by-sea, UK \\ *Email: M.Bernagozzi2@ brighton.ac.uk
}

\begin{abstract}
A novel cooling method for Electric Vehicles battery modules by means of Loop Heat Pipe and graphite sheets is proposed. The Loop Heat Pipe is a passive two-phase system and as such it reduces the parasitic power consumed by the $E V$ thermal management. A validated lumped parameter mathematical model has been created describing the thermo-fluid-dynamic problem and used to simulate the performance of the cooling system during highway driving and ultra-fast charging conditions. The numerical predictions show a clear potential to contain the cells' temperature below $40^{\circ} \mathrm{C}$ even during ultra-fast charging, with a $3.3 \mathrm{~K}$ peak temperature reduction in comparison to a conventional liquid cooling method. Moreover, this system adds only $8 \%$ of the battery pack mass and it shows potential parasitic power reductions of one order of magnitude.
\end{abstract}

\section{INTRODUCTION}

Temperature is a crucial influencing factor on the behaviour of the battery pack of an Electric Vehicle (EV). In fact, at low temperature, plating phenomena and reduced electrolytic ionic conductivity reduce the power output and cell capacity. For instance at $-10^{\circ} \mathrm{C}$, the available energy of the cell is $60 \%$ of the normal ambient temperature value [1]. Similarly, at high temperatures, the dissolving of the Solid Electrolyte Interphase (SEI) leads to electrolytic corrosion of the anode thus reducing the energy and power output. For instance, at $55^{\circ} \mathrm{C}$ the battery capacity is only $30 \%$ of the corresponding value at normal ambient temperature [2]. Additionally, when cell temperature reaches $\sim 130^{\circ} \mathrm{C}$ (i.e. melting of the separator), the onset of a self-sustained reaction called "thermal runaway" occurs, which leads to temperature increases up to $500^{\circ} \mathrm{C}$, and eventually to smoke, fire or even explosion [3]. Therefore, a successful battery Thermal Management System (TMS) for an EV has strict requirements, subdivided in three system levels: at cell level, the temperature gradient across the cell surface needs to be maintained between $3-5^{\circ} \mathrm{C}$; at module level temperature homogeneity needs to be respected, hence the temperature difference between the cells of one module should not be greater than $5^{\circ} \mathrm{C}$; overall, at pack level, the cell temperature for optimum performance and operative life needs to be maintained between $25^{\circ} \mathrm{C}$ and $40^{\circ} \mathrm{C}$.

Currently, automotive manufacturers are relying on single phase, air and liquid convection to fulfill the abovementioned requirements. Using air convection is simple and cheap, thanks to a series of fans and intakes that are used to direct the airstream into the battery pack. However, due to the poor thermal properties of the thermal medium, air convection is not efficient enough to respect the module and pack requirements at high C-rates (Charge-rate, defined as the charge or discharge current divided by the nominal capacity of battery). Moreover, due to the power required by the fans, it can consume up to 10 times more parasitic power than liquid convection [4]. The latter employs a liquid working fluid in tubing, cold plates or jackets, providing excellent heat transfer coefficients and, once optimizing mass flow rates and pressure drops, it can consume less power than air convection. Nevertheless, a liquid TMS includes several components, thus increasing cost, weight and the needs of maintenance.

The choice of the TMS plays a crucial role in the design of an EV, as it directly influences the perceived barriers stopping customers from purchasing an EV. From a recent survey [5], these are: 1) limited range of the vehicle, 2) high cost of ownership and 3) long charging time. Minimizing the parasitic power consumption of the TMS and increasing its energy dissipation density (more compact battery pack) would increase the BEV electric range. Moreover, reducing the TMS complexity, the number of parts and the needs for maintenance will help reducing the costs. Finally, having a more efficient TMS that can dissipate high heat fluxes can reduce the time required for charging, allowing for higher C-rates.

Aiming to overthrow these barriers, the present work proposes a novel TMS employing Loop Heat Pipes (LHPs), to transfer heat from a pouch cell module to a heat sink. The pouch cells are sandwiched between graphite sheets, with the twofold function to even the cell surface temperature and to delay thermal runaway spreading. A lumped parameter mathematical model has been developed and used to simulate the performance over a driving cycle composed by highway driving followed by ultra-fast charging (less than 15 minutes 5C maximum C-Rate) and then another set of highway driving, until depletion of the charge. Results were then compared with a conventional TMS employing a liquid cold plate running with ethylene glycol.

\section{LHP THERMAL MANAGEMENT SYSTEM DESCRIPTION}

\section{A. Loop Heat Pipe Fundamentals}

The Loop Heat Pipe (LHP) is a passive two-phase device, part of the Heat Pipe family. As such, it removes and transfers heat thanks to cycles of evaporation and condensation of a working fluid in a partially filled and evacuated container [6]. In Fig. 1, a schematic displaying the characteristic parts is reported. 


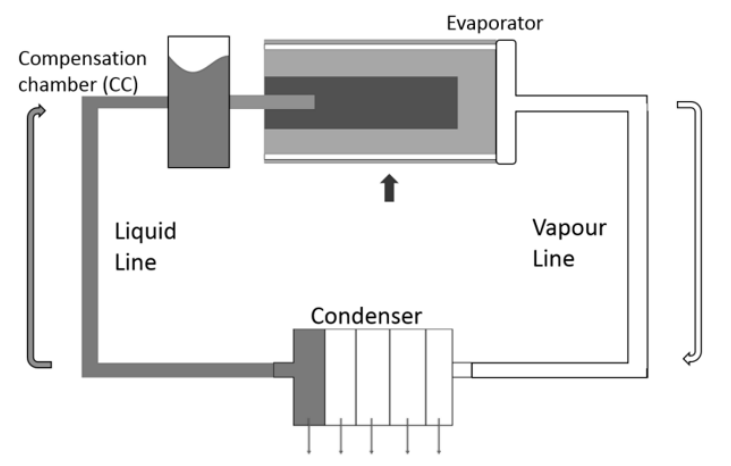

Fig. 1. LHP Schematic [7].

The operating principle is as follows: when heat is applied to the evaporator, the working fluid changes phase from liquid to vapour. Thanks to the pressure gradient applied by the capillary pores in the porous structure, called wick, the fluid can only go in one direction and hence it travels to the condenser via the vapour line. Heat is rejected to a cold source in the condenser and the newly formed liquid travels back to the compensation chamber and finally back to the evaporator.

The compensation chamber has the twofold function to regulate the saturation temperature in the loop and to feed working fluid to the evaporator in case it gets dry. Thanks to the capillary pressure gradient provided by the wick, these devices do not need any electrical power source or mechanical power parts to function and to transfer heat from one end to the other. Moreover, since the wick is present in the evaporator only, they allow for heat transportation over much longer distances than the standard heat pipes (e.g. $20 \mathrm{~m}$ ), at a lower production cost.

\section{B. Novel Thermal Management System Design}

The TMS presented in this work envisages the use of LHPs to transfer heat from a battery module to a remote heat sink connected to a liquid chiller loop. The module is composed of a staggered array of pouch cells and graphite sheets assemblies (Fig. 2). Having a compact chiller loop (e.g. a liquid loop running a refrigerant with the sole purpose of cooling the condenser of the LHP) instead of a liquid loop travelling across the whole battery pack, will reduce the system complexity. Moreover, the reduced length of the chiller's tubing will reduce the load losses of the chiller' pump, effectively allowing for a less powerful pump, leading to a decrease in the parasitic power consumption and thus an increase in the available range.

LHPs are preferred to standard wicked Heat Pipes (HPs) due to the benefit they provide in terms of long distance heat transportation; in fact, thanks to having the wick in the evaporator only, LHPs are able to provide heat transportation up to several meters at a lower unit cost than a standard wicked HP of the same length. In this purpose, LHPs have been preferred to Pulsating Heat Pipes (PHPs) as the latter still presents uncertainties on their sensitivity to external accelerations, which could make their applicability to a moving vehicle troublesome.

Graphite sheets are chosen thanks to their favorable anisotropic properties in terms of thermal conductivity. In fact,

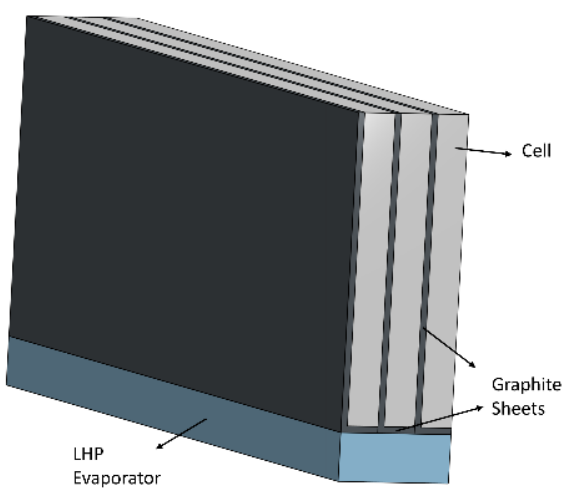

Fig. 2. Schematic of the TMS proposed in this work applied to a 3-cells module. The same geometry has been employed in the FEA validation processes.

due to its woven structure, graphite has high thermal conductivity in the in-plane direction, whereas in the perpendicular plane (thruplane, Table I) the thermal conductivity is generally two orders of magnitude lower. As such, graphite allows for good heat transfer in the vertical direction of the cell to the LHP and it acts as a way of thermal insulation to and from the adjacent cells; which ultimately can improve thermal runaway protection and/or delay.

The simulated pack has 4 modules of 105 cells each, for a total of 420 cells. TABLE I shows the data of the selected cells. In the proposed TMS, 8 LHPs are used, one every 52 cells. Ambient temperature is kept fixed at $20^{\circ} \mathrm{C}$. LHP specifications are presented in TABLE II. The chosen working fluid is distilled water.

TABLE I.

POUCH CELLS DATA SPECIFICATIONS FOR LPM MODELS.

\begin{tabular}{lcc}
\hline Parameter & Value & Units \\
\hline Thickness & 10 & $\mathrm{~mm}$ \\
Height & 96 & $\mathrm{~mm}$ \\
Width & 280 & $\mathrm{~mm}$ \\
Thermal Conductivity inplane & 46 & $\mathrm{~W} / \mathrm{m} \cdot \mathrm{K}$ \\
Thermal Conductivity thruplane & 0.7 & $\mathrm{~W} / \mathrm{m} \cdot \mathrm{K}$ \\
Density & 3720 & $\mathrm{~kg} / \mathrm{m}^{3}$ \\
Mass Heat Capacity & 1726 & $\mathrm{~J} / \mathrm{kg} \cdot \mathrm{K}$ \\
Capacity & 65 & $\mathrm{Ah}$ \\
\hline
\end{tabular}

\section{Lumped Parameter Modelling}

To evaluate the feasibility of such design, a Lumped Parameter Model (LPM) was created to calculate temperature increments and the heat distribution for the cell-graphite assembly and the LHP, during different driving cycles.

Firstly, the LPM for the cell-assembly is created (Fig. 3). The heat generation rate of a battery can be described from the equation proposed by Bernardi et al. [8]:

$$
\dot{Q}=I\left(U-V-T \frac{d U}{d T}\right)
$$

where $I$ is the current, $T$ the temperature $[\mathrm{K}], U$ the open circuit voltage (which is the potential difference existing when no load is connected to the circuit) and $V$ is the working voltage of the cell. The first term on the right side of (1) is the irreversible over potential heat due to Ohmic losses in the cell, chargetransfer over potentials at the interface, and mass transfer limitations. The second term is reversible entropic heat from 
TABLE II.

DATA SPECIFICATIONS OF THE LHP.

\begin{tabular}{|c|c|c|c|}
\hline & & Value & Units \\
\hline \multirow{3}{*}{$\begin{array}{l}\text { Condenser } \\
\text { (Stainless Steel) }\end{array}$} & Internal Radius & 3 & $\mathrm{~mm}$ \\
\hline & Outer Radius & 4 & $\mathrm{~mm}$ \\
\hline & Length & 40 & $\mathrm{~cm}$ \\
\hline \multirow{4}{*}{$\begin{array}{l}\text { Liquid Line } \\
\text { (Stainless Steel) }\end{array}$} & Internal Radius & 3 & $\mathrm{~mm}$ \\
\hline & Outer Radius & 4 & $\mathrm{~mm}$ \\
\hline & Elevation & 20 & $\mathrm{~cm}$ \\
\hline & Length & 45 & $\mathrm{~cm}$ \\
\hline \multirow{4}{*}{$\begin{array}{l}\text { Vapour Line } \\
\text { (Stainless Steel) }\end{array}$} & Internal Radius & 3 & $\mathrm{~mm}$ \\
\hline & Outer Radius & 4 & $\mathrm{~mm}$ \\
\hline & Elevation & 20 & $\mathrm{~cm}$ \\
\hline & Length & 45 & $\mathrm{~cm}$ \\
\hline \multirow{6}{*}{$\begin{array}{l}\text { Wick } \\
\text { (Nickel) }\end{array}$} & Radius & 20 & $\mathrm{~mm}$ \\
\hline & Length & 15 & $\mathrm{~cm}$ \\
\hline & Vapour Grooves Radius & 1 & $\mathrm{~mm}$ \\
\hline & Vapour Grooves Number & 10 & - \\
\hline & Porosity & $60 \%$ & - \\
\hline & Mean Pore Radius & 1.2 & $\mu \mathrm{m}$ \\
\hline \multirow{3}{*}{$\begin{array}{l}\text { Evaporator } \\
\text { (Stainless Steel) }\end{array}$} & Wall thickness & 2 & $\mathrm{~mm}$ \\
\hline & Bayonet Radius & 3 & $\mathrm{~mm}$ \\
\hline & Length & 75 & $\mathrm{~mm}$ \\
\hline \multirow{2}{*}{$\begin{array}{l}\text { Compensation Chamber } \\
\text { (Stainless Steel) }\end{array}$} & Length & 20 & $\mathrm{~mm}$ \\
\hline & Internal Radius & 6 & $\mathrm{~mm}$ \\
\hline
\end{tabular}

electrochemical reactions, which is usually neglected in thermal problems [9].

In order to simulate the whole module, it is assumed that the cells are following the same temperature evolution. Thus, the heat applied to the LHP is calculated by multiplying the heat transferred by a single cell, by the number of cells.

Other assumptions of the model are: perfect thermal contact between the surfaces; electrolytic convection inside the battery is neglected; inside the coupled cell-graphite control volume, only heat transfer by conduction is considered; top and sides of the cell are in contact with ambient air at room temperature and hence free convection heat transfer is considered; in accordance with the industrial collaborator recommendation, pouch cells are chosen as cell type.

On Fig. 3, the thermal network describing the thermal behavior of such system is presented. Since the coupling between cell and graphite represents a periodic problem (i.e. a succession of stacked identical cell-graphite assemblies), it was deemed acceptable to simulate only one iteration of the module. The cell is divided in three nodes in order to investigate also the fulfilling of the thermal requirement at cell level. The graphite sheet model has been divided in four nodes, where the top three are mirroring the same position of the equivalent cell nodes, while the fourth represents the thermal interface at the bottom between the cell and the LHP evaporator. The thermal network presented in Fig. 3 leads to a system of ODE having a formulation as expressed in (2):

$$
\begin{aligned}
& m_{c} c_{p} \frac{d T_{c 1}}{d t}=q_{1}+\frac{T_{a m b}-T_{c 1}}{R_{a m b c}+R_{c \|} / 2}+\frac{T_{g 1}-T_{c 1}}{R_{g \perp}+R_{c \perp}}+\frac{T_{c 2}-T_{c 1}}{R_{c \|}} \\
& m_{c} c_{p} \frac{d T_{c 2}}{d t}=q_{2}+\frac{T_{c 1}-T_{c 2}}{R_{c \|}}+\frac{T_{g 2}-T_{c 2}}{R_{g \perp}+R_{c \perp}}+\frac{T_{c 3}-T_{c 2}}{R_{c \|}} \\
& m_{c} c_{p} \frac{d T_{c 3}}{d t}=q_{3}+\frac{T_{c 2}-T_{c 3}}{R_{c \|}}+\frac{T_{g 3}-T_{c 3}}{R_{g \perp}+R_{c \perp}}+\frac{T_{g 4}-T_{c 3}}{R_{c \|}+R_{g \perp} / 2}
\end{aligned}
$$

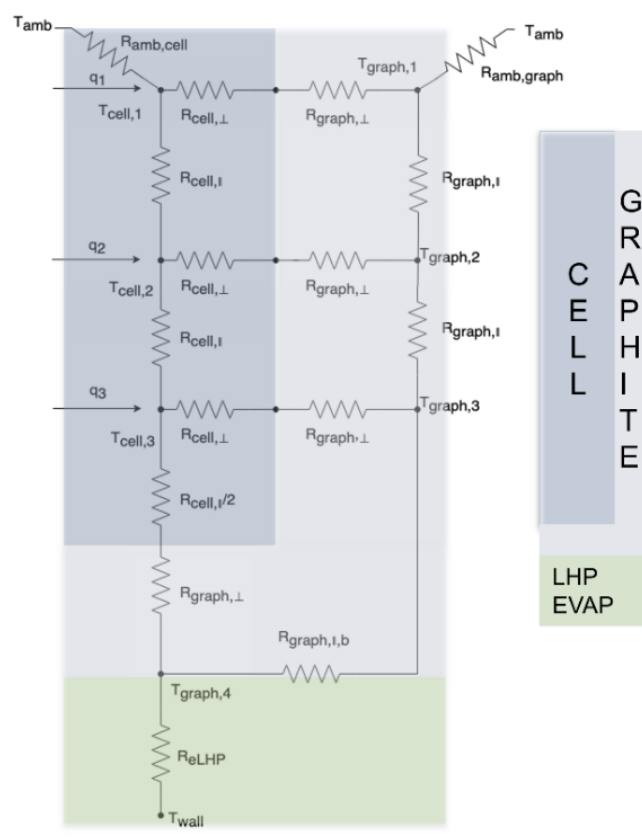

Fig. 3. Thermal network of cell-graphite assembly. The different color blocks help to identify the different regions: cell, graphite sheet and LHP evaporator.

$$
\begin{aligned}
& m_{g} c_{p} \frac{d T_{g 1}}{d t}=\frac{T_{a m b}-T_{g 1}}{R_{a m b g}+R_{g \|} / 2}+\frac{T_{c 1}-T_{g 1}}{R_{g \perp}+R_{c \perp}}+\frac{T_{g 2}-T_{g 1}}{R_{g \|}} \\
& m_{g} c_{p} \frac{d T_{g 2}}{d t}=\frac{T_{g 1}-T_{g 2}}{R_{g \|}}+\frac{T_{c 2}-T_{g 2}}{R_{g \perp}+R_{c \perp}}+\frac{T_{g 3}-T_{g 2}}{R_{g \|}} \\
& m_{g} c_{p} \frac{d T_{g 3}}{d t}=\frac{T_{g 2}-T_{g 3}}{R_{g \|}}+\frac{T_{c 3}-T_{g 3}}{R_{g \perp}+R_{c \perp}}+\frac{T_{g 4}-T_{g 3}}{R_{g \| b}} \\
& m_{g} c_{p} \frac{d T_{g 4}}{d t}=\frac{T_{w a l l}-T_{g 4}}{R_{e L H P}}+\frac{T_{c 3}-T_{g 4}}{R_{g \perp}+R_{c \perp} / 2}+\frac{T_{g 3}-T_{g 4}}{R_{g \| b}}
\end{aligned}
$$

where the suffixes $c, g$ refer to cell and graphite respectively; the terms on the left are the thermal capacities of the i-th node; on the right there are all the heat flux components entering or exiting the i-th node: the heat generated by the cell node $q_{i}$ (obtained from (1)) and the heat flux coming from the other adjacent nodes in the form of $\Delta T / R$. All the resistances in the thermal network of Fig. 3 consider heat transfer via conduction, considering the anisotropic properties of both the cell and the graphite sheets (inplane $\|$, and thruplane $\perp$ ), with the exception of the free convection resistance $R_{a m b}$.

The described model has been integrated with another LPM describing the thermodynamic behavior of a LHP, previously developed and validated by the authors [7]. Fig. 4 shows the thermal network for the LHP evaporator, which receives as thermal input a fictious varying power $\dot{Q}_{\text {ext }}$, usually indicated as the thermal power generated by the component that needs cooling. In this case, the heat input to the LHP is not the same as generated by the cell. Due to the strongly transient behaviour of the heat generation rate in a cell subjected to a driving cycle, the thermal inertia effects in the cell itself as well as in the graphite play a major role. Therefore, the heat input inside the LHP is the resultant of the difference between the heat created 


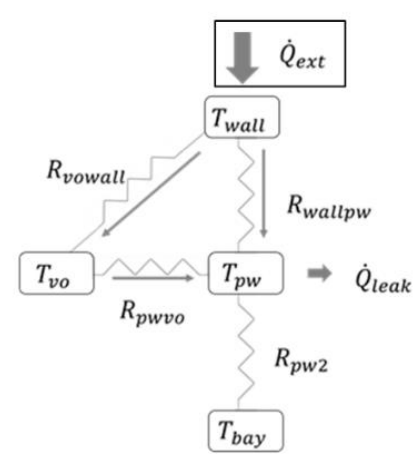

Fig. 4. Thermal Network describing the LHP evaporator [7].

by the cell and the heat stored in the material of cell and graphite, as expressed in (9).

$$
\dot{Q}_{\text {ext }}=\frac{T_{\text {graph }, 4}-T_{\text {wall }}}{R_{\text {eLHP }}} n_{\text {module }}
$$

The two models are linked by the LHP evaporator wall node, present in both thermal networks of Fig. 3 and Fig. 4, allowing thus to calculate the temperature distribution for the cellgraphite assembly and its effect on the thermal performance of the LHP.

\section{Validation Procedures}

The LHP model was previously validated for three different geometries, materials and three different working fluids (water, ammonia, R134a) thanks to experimental data published in literature [7]. Afterwards, for the cell-graphite assembly, a validation procedure was carried out by means of FEA simulations on ANSYS Fluent $18.2^{\circledR}$. Comparison was made between the cell temperature resulting from the proposed LPM and the FEA model under the same boundary conditions of free convection to the top of both cell and graphite. The material properties are listed in Table III. Graphite values come from Panasonic PGS sheet while cell equivalent properties were provided by Ricardo plc.

To replicate the heat generation rate of the cell, a volumetric heat generation value has been set dividing the total heat generated from the cell by its volume. The LHP evaporator wall is fixed at a constant temperature of $20^{\circ} \mathrm{C}$. Thus, temperature in the cell will increase until thermal equilibrium is reached, which is when the heat flux reaching the LHP evaporator wall equals the total generated from the cell (minus the small losses for free convection).

The thermal network has been implemented in Octave v5.2.0, with the same physical properties and boundary conditions. Similarly, the value $T_{\text {wall }}$ in equation (8) has been kept constant at $20^{\circ} \mathrm{C}$ and the simulation has been left running until steady state conditions were reached. The value $q_{i}$ has been set as a third of the total heat generated value imposed on the FEA simulation. Two heat conditions were considered, low heat rate $(3 \mathrm{~W})$ and high heat rate $(30 \mathrm{~W})$, but for space limitations only the high heat rate results are presented in Fig. 5 for the FEA and Fig. 6 for the three cell nodes.
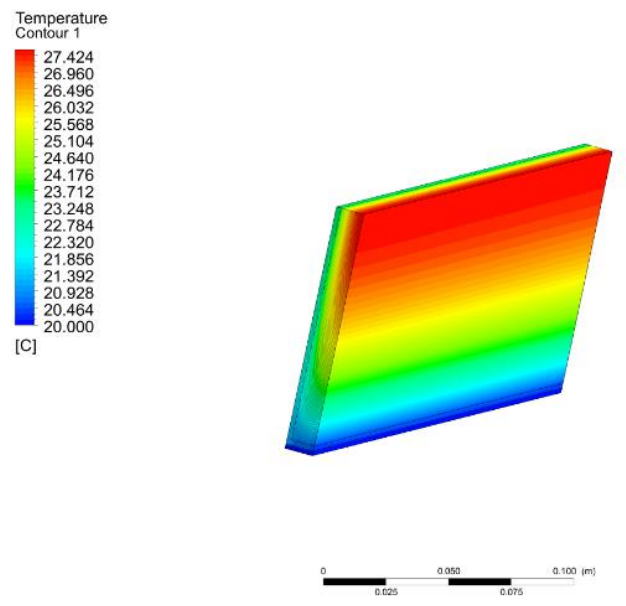

Fig. 5. FEA results with $30 \mathrm{~W}$ heat generation rate.

The comparison of the results shows an excellent match in the maximum temperature calculated by the two models $\left(27.42^{\circ} \mathrm{C}\right.$ for the FEA and $27.34^{\circ} \mathrm{C}$ for the LPM), giving a $\Delta T$ of $0.08^{\circ} \mathrm{C}$.

TABLE III.

MATERIAL PROPERTIES USED IN THE VALIDATION PROCESSES.

\begin{tabular}{cccc}
\hline Material & $\begin{array}{c}\text { Density } \\
{\left[\mathrm{kg} / \mathrm{m}^{3}\right]}\end{array}$ & $\begin{array}{c}\text { Thermal conductivity } \\
{[\mathrm{W} / \mathrm{m} \mathrm{K}]}\end{array}$ & $\begin{array}{c}\text { Specific Heat } \\
{[\mathrm{J} / \mathrm{kg} \mathrm{K}]}\end{array}$ \\
\hline Cell & 3720 & $46-0.7$ & 1726 \\
Graphite & 1716 & $600-3.5$ & 810 \\
SS & 7800 & $14.4-14.4$ & 502 \\
\hline
\end{tabular}

This, in addition to the previous validation campaign on the LHP model, gives enough confidence to move forward with the numerical activities. The next section will show the results of the simulation on the performance of the TMS proposed in this work on a fast charge driving cycle.

\section{HighWAY AND FAST ChARGE DRIVING CYCLE}

\section{E. Driving Cycle Description}

Since fast charging and its thermal management is one of the main focus and challenge regarding EVs, a custom Highway -

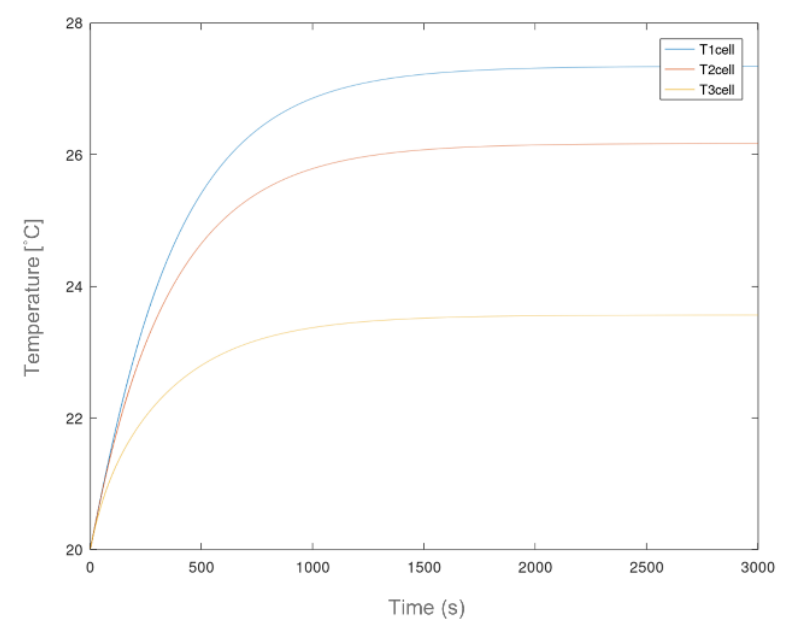

Fig. 6. Cell-graphite assembly LPM results under $30 \mathrm{~W}$ heat generation rate. 
Fast Charge - Highway ( $\mathrm{HFCH}$ ) driving cycle is created here, divided in three steps: highway driving until depletion of the charge, ultra-fast charge from $0 \%$ to $80 \%$ SOC and finally another identical highway driving section till depletion of the charge. In TABLE IV a breakdown of the C-rates used in this driving cycle is presented. It can be noted that two cooldown periods of 1 minute each have been introduced to mimic a reallife scenario where before and after charge, the driver will have to detach the socket and re-enter and re-start the car.

The trend of the heat generation rate of a single cell is presented in Fig. 7, showing a peak heat generation of 54W.

\section{F. Liquid Cooling Comparison}

In order to evaluate the potential feasibility of the use of LHP instead of liquid cooling, the design proposed in this work is compared against a TMS developed by the industrial collaborator Ricardo which foresees the use of aluminum side plates to transfer heat from the side surface of the cell to a liquid cold plate placed at the bottom of the module (similarly to the LHP), as presented in Fig. 8a. This cold plate is part of a liquid cooling loop connected to a heat exchanger and a pump, running ethylene glycol at a constant temperature of $20^{\circ} \mathrm{C}$.

TABLE IV.

HIGHWAY - FAST CHARGE - HIGHWAY (HFCH) DRIVING CYCLE C-RATES AND SOC.

\begin{tabular}{cccc}
\hline C-rate & Duration $(\min )$ & SOC & \\
\hline-1 & 59 & $2 \%$ & Highway \\
-0.5 & 2.5 & $0 \%$ & Driving \\
\hline 0 & 1 & $0 \%$ & \\
5 & 2 & $16 \%$ & \\
4 & 4 & $43 \%$ & \\
3 & 5 & $68 \%$ & Fast Charging \\
2 & 3 & $78 \%$ & \\
1 & 1 & $80 \%$ & \\
0 & 1 & $80 \%$ & \\
\hline-0.5 & 3 & $77 \%$ & Highway \\
-1 & 46 & $0 \%$ & Driving \\
\hline
\end{tabular}

This cooling system has been modelled with a 3D LPM that was then implemented in MATLAB Simulink. Every cell in the module is represented by one cell model such as the one presented in Fig. 8b, consisting of 3 nodes, one for the plate itself and one for the bottom and top surface. This model accounts for both the temperature rise over time of the cooling fluid and the spatial temperature difference from cell to cell.

Cell Heat Release [W]

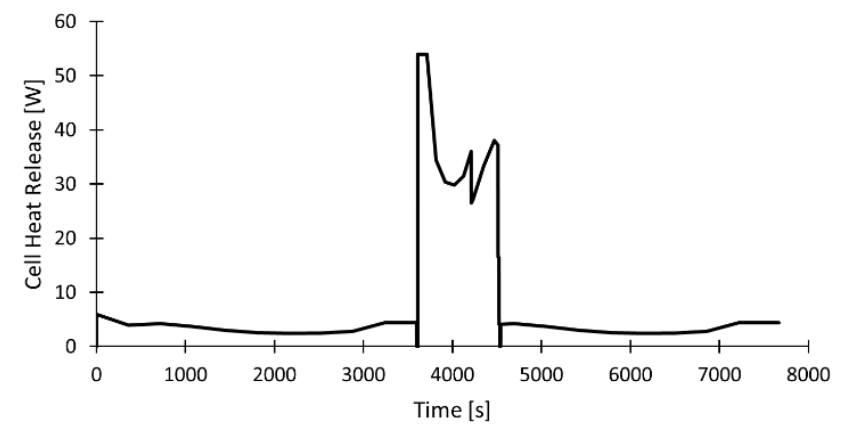

Fig. 7. Cell heat generation rate during the HFCH driving cycle.

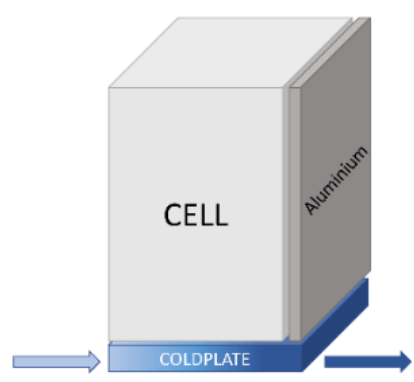

(a)

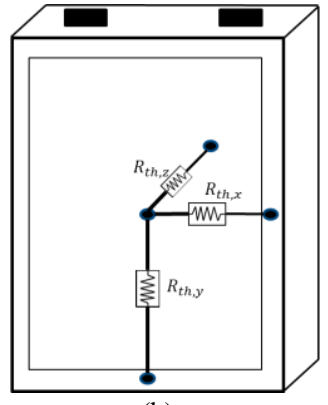

(b)
Fig. 8. Schematic of the liquid cold plate TMS used as benchmark (a) and the3D LPM used to describe the cell.

The fluid flows through the channels inside the cold plate and cools the cell indirectly by cooling the cold plate. The side plate is solid without cooling channels inside. It is connected to the cold plate on the bottom of the plate. The heat conduction through the cell is modelled based on the Cauer-Model [10] where the cell heat transfer is represented through an individual layer of semiconductor module.

\section{G. Results}

Looking at the comparison over the average cell temperatures for the two TMS solutions during the $\mathrm{HFCH}$ driving cycle presented in Fig. 9 it shows that not only the solution proposed in this work is feasible, but that it also can provide great benefit in terms of maximum temperature reduction during ultra-fast charging, with a potential $8 \%$ improvement in cooling performance. The LHP based TMS is able to fulfill the thermal requirement at pack level, providing a peak temperature of $36.6^{\circ} \mathrm{C}$ during fast charge, contributing to a $3.3^{\circ} \mathrm{C}$ reduction against the maximum temperature of $39.8^{\circ} \mathrm{C}$ reached with the liquid cold plate TMS. Moreover, the TMS proposed in this work allows for a faster temperature reduction after fast charging, with the two solutions exhibiting $6.6^{\circ} \mathrm{C}$ of difference at the end of the driving cycle. In addition, the maximum $\Delta T$ between the three cell nodes is $1.6^{\circ} \mathrm{C}$, proving that this method can also fulfill the thermal requirement at cell level.

One of the most appealing traits of the use of the LHP lies in the passive nature of this device. In fact, thanks to the absence of a need for an external source of motion for the fluid, a pump is needed to circulate the refrigerant only for the heat exchanger used to cool down the condenser of the LHP. In the liquid cooling loop used as comparison, the pump needs to provide a pressure gradient sufficient for the fluid to travel the entirety of the battery pack length. This will adversely affect the all-electric range of the vehicle.

In order to gauge the benefit of using a passive two-phase device on the power consumption, the mass flow rate at the heat exchanger side was calculated. In the LPM, a section implementing the $\varepsilon$-NTU method was added. Thanks to this, it was possible to plot the trend of the mass flow rate required at the heat exchanger to ensure full condensation and no subcooling at the end of the all condensers of the LHPs (Fig. 10). The curve spikes shortly before 4000 seconds because this 


\section{Comparison $\mathrm{HFCH}$}

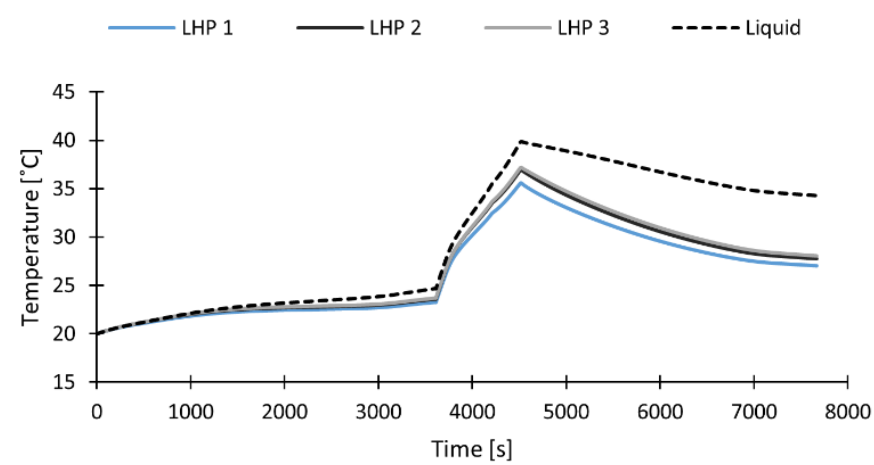

Fig. 9. Average cell temperature during the HFCH driving cycle for the two thermal management systems: LHP (this work) and liquid (benchmark).

is when the LHP start up occurs, hence before there is no working fluid circulating in the LHP. This spike can be easily avoided when a regulation system is incorporated, for example controlling the maximum flow rate at $0.05 \mathrm{~kg} / \mathrm{s}$, without any issue with the temperatures.

From the information provided by the industrial collaborator, the volumetric flow rate for the cold plate liquid TMS amounts to be $201 / \mathrm{min}$. Knowing that the mass flow rate is the product of the volumetric flow rate for the fluid density, for ethylene glycol $\left(\rho=1110 \mathrm{~kg} / \mathrm{m}^{3}\right)$ this gives $\dot{m}$ of $0.37 \mathrm{~kg} / \mathrm{s}$.

From Fig. 10, it is evident how substantial this difference in mass flow rate is. Unfortunately, no information on the pump power or head are provided for the cooling loop, hence it is not possible to compare the power consumption of the two thermal management systems. However, considering the relationship between mass flow rate and pump power, it is reasonable to assume that the reduction of one order of magnitude in mass flow rate will reflect in a similar reduction of the parasitic power required by the pump.

Looking at the mass budget, considering 8 LHPs and same HEXs plus the added graphite sheet weight, the total added mass of the proposed TMS is $35.4 \mathrm{~kg}$. The breakdown of the mass budget is presented in TABLE V. Considering that the total mass for the cells amounts to $420 \mathrm{~kg}$, the added mass for the TMS is only the $8 \%$.

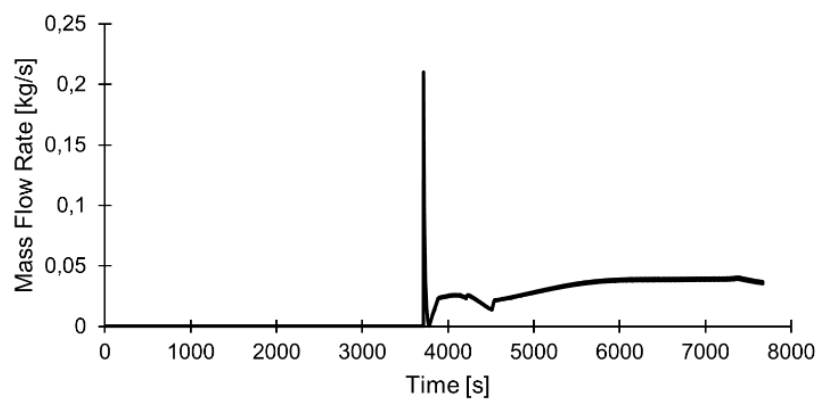

Fig. 10. Mass flow rate required in the heat exchanger to provide full condensation and no subcooling to all the LHPs applied to the pack.
TABLE V.

TOTAL MASS BREAKDOWN OF THE PROPOSED TMS CONSIDERING A BATTERY PACK COMPOSED BY 420 CELLS

\begin{tabular}{lcc}
\hline Part & Mass [kg] & Total [kg] \\
\hline LHP & 1.5 & 14.4 \\
HEX & 0.3 & 21 \\
Graphite Sheet & 0.05 & 35.4 \\
TMS & & 420 \\
Pouch Cell & 1 & \\
\hline
\end{tabular}

\section{CONCLUSIONS}

A novel TMS for battery module has been proposed by utilization of Loop Heat Pipe and graphite sheets, in order to reduce the customers' barriers towards EVs, particularly the all-electric range. Numerical results show how this method is able to keep cell temperature below the selected threshold of $40^{\circ} \mathrm{C}$ even during ultra-fast charging operations (5C). Compared to standard liquid cold plate cooling, the TMS proposed in this work can reduce the peak temperature by $3.3^{\circ} \mathrm{C}$. Moreover, evidence has been provided that this solution, as expected, can potentially reduce the parasitic power consumption by one order of magnitude whilst adding less than $10 \%$ of the cells mass, hence potentially increasing the allelectric range.

\section{ACKNOWLEDGMENT}

The Authors would like to acknolwdge Ricardo plc for the financial support and Christian Orner for the battery modelling support. The Authors would like also to thank the Advanced Engineering Centre and the School of Computing, Engineering and Mathematics at the University of Brighton.

\section{REFERENCES}

[1] M. R. Giuliano, A. K. Prasad, and S. G. Advani, "Experimental study of an air-cooled thermal management system for high capacity lithiumtitanate batteries," J. Power Sources, vol. 216, pp. 345-352, 2012.

[2] P. Ramadass, B. Haran, R. White, and B. N. Popov, "Capacity fade of Sony 18650 cells cycled at elevated temperatures," J. Power Sources, vol. 112 , no. 2 , pp. 614-620, 2003.

[3] X. Feng, M. Ouyang, X. Liu, L. Lu, Y. Xia, and X. He, "Thermal runaway mechanism of lithium ion battery for electric vehicles: A review," Energy Storage Mater., vol. 10, no. December 2016, pp. 246 $267,2018$.

[4] D. Chen, J. Jiang, G. H. Kim, C. Yang, and A. Pesaran, "Comparison of different cooling methods for lithium ion battery cells," Appl. Therm. Eng., vol. 94, pp. 846-854, 2016.

[5] L. Noel, G. Zarazua de Rubens, B. K. Sovacool, and J. Kester, "Fear and loathing of electric vehicles: The reactionary rhetoric of range anxiety," Energy Res. Soc. Sci., vol. 48, no. April 2018, pp. 96-107, 2019.

[6] Y. F. Maydanik, "Loop heat pipes," Appl. Therm. Eng., vol. 25, no. 5-6, pp. 635-657, 2005.

[7] M. Bernagozzi, S. Charmer, A. Georgoulas, I. Malavasi, N. Michè, and M. Marengo, "Lumped parameter network simulation of a Loop Heat Pipe for energy management systems in full electric vehicles," Appl. Therm. Eng., vol. 141, pp. 617-629, 2018.

[8] D. Bernardi, E. Pawlikowski, and J. Newman, "General Energy Balance for Battery Systems.," J. Electrochem. Soc., vol. 132, no. 1, pp. 5-12, 1985.

[9] H. Fathabadi, "A novel design including cooling media for Lithium-ion batteries pack used in hybrid and electric vehicles," J. Power Sources, 2014.

[10] Z. Zhou, P. M. Holland, and P. Igic, "Compact thermal model of a threephase IGBT inverter power module," in "2008 26th International Conference on Microelectronics, Proceedings, MIEL 2008,” 2008. 